\title{
Analysis of Serotypes and Electropherotypes of Equine Rotaviruses Isolated in the United States
}

\author{
MICHELE E. HARDY, ${ }^{1}$ GERALD N. WOODE, ${ }^{1 *}$ ZHICHANG XU, ${ }^{1}$ JOHN D. WILLIAMS, ${ }^{1}$ \\ MARGARET E. CONNER, ${ }^{2}$ ROBERTA M. DWYER, ${ }^{3}$ AND DAVID G. POWELL ${ }^{3}$ \\ Department of Veterinary Pathobiology, College of Veterinary Medicine, Texas A\&M University, \\ College Station, Texas 77843-4467 ${ }^{1}$; Department of Virology, Baylor College of Medicine, \\ Houston, Texas 77030² and Department of Veterinary Science, Gluck Equine \\ Research Center, College of Agriculture, University of Kentucky, \\ Lexington, Kentucky 40546-00993
}

Received 27 August 1990/Accepted 4 February 1991

\begin{abstract}
Equine group A rotaviruses isolated over a 10-year period in New York State, New Jersey, Kentucky, and Texas were compared serotypically and electropherotypically. All isolates were determined to be serotype 3 by reaction with hyperimmune antiserum to the serotype 3 H-2 strain of equine rotavirus. All displayed RNA electrophoretic migration patterns related to that of the H-2 strain but distinct from that of serotype 5 strain H-1. A serologic survey of 184 mares in Kentucky, which was done to determine the incidence of H-1 and H-2 infections, showed geometric mean serum neutralizing titers to the $H-2$ strain of equine rotavirus to be significantly higher than those to the H-1 strain. These data suggest that the serotype $3 \mathrm{H}-2$ strain is the dominant equine rotavirus in Kentucky and perhaps elsewhere in the United States. We were unable to produce confirmational evidence that the $\mathrm{H}-1$ strain occurs as a natural infection in the United States.
\end{abstract}

The first report describing an equine rotavirus was by Flewett et al. (8) in Great Britain in 1975. This isolate was subsequently adapted to growth in tissue culture in the United States and was designated H-1 (14). A second isolate, $\mathrm{H}-2$, was studied in Great Britain (21) and was cultured and identified in the United States as a distinct serotype (15). The equine rotavirus isolates $\mathrm{H}-1$ and $\mathrm{H}-2$ were shown to be serotypically distinct from each other and from some other mammalian rotaviruses. Subsequently, $\mathrm{H}-1$ was assigned to the rotavirus serotype 5 group (shared with the OSU strain of porcine rotavirus) and $\mathrm{H}-2$ was assigned to the rotavirus serotype 3 group (shared with human type 3 , simian, and canine rotaviruses) (13). This serotyping is based on the antigenic properties of VP7 (usually encoded in gene 9), which is one of two outer capsid proteins which stimulates production of neutralizing antibodies. For most rotaviruses, including the equine strains, little is known about the comparative antigenic properties of the other outer capsid protein, VP4 (encoded in gene 4), which has also been shown to stimulate the production of neutralizing antibodies $(11,17)$.

Rotaviruses have been isolated during severe epidemics of foal diarrhea in Australia (20), the United States $(3,16)$, and New Zealand (4). In a recent study of enteric diseases in thoroughbred and standardbred foals in central Kentucky (5), foals on three of five farms monitored had outbreaks of diarrhea, with 43 of 201 (21.4\%) fecal samples being positive for rotavirus. In 1988, outbreaks of foal diarrhea on 12 farms were investigated (6). Of 196 sick foals tested, 104 (53\%) were positive for rotavirus. The ages of the foals affected ranged from 2 to more than 120 days, with younger foals consistently being more severely affected and with some requiring intensive care. During the 2 -year survey, only a single foal (age, 2 days) died from rotavirus enteritis.

Rotavirus-containing foal fecal samples from these sur-

\footnotetext{
* Corresponding author.
}

veys, other thoroughbred and standardbred foals in New York State and New Jersey $(1980,1989)$, and a quarter horse foal in Texas (1988) were studied to determine the electropherotype and serotype of each rotavirus for comparison with those of the $\mathrm{H}-1$ and $\mathrm{H}-2$ strains. A serologic survey was also made by using serum samples obtained from the mares in the Kentucky study to determine the incidence of antibody response to and relative importance of serotype 3 and serotype 5 rotaviruses in this population.

\section{MATERIALS AND METHODS}

Viruses. The equine rotavirus strains $\mathrm{H}-1$ and $\mathrm{H}-2$, together with typing hyperimmune guinea pig antisera, were kindly supplied by T. Hoshino, National Institutes of Health, Bethesda, Md. The FI-13 and FI-14 strains were originally isolated from standardbred foals with diarrhea in New York State and New Jersey, respectively, in 1980 (10). All of the following isolates were obtained from foals with diarrhea. Of the Kentucky isolates, E56, E77, and E149 were isolated from standardbred foals; and isolates E26, E30, E48, E50, E143, and E149 were isolated from thoroughbred foals. Isolate E7 was originally isolated from a quarter horse foal in Texas in 1988, and isolate E161 was originally isolated from a thoroughbred foal in New York State in 1989. Isolate KY-1 was originally isolated from a standardbred foal in Kentucky in 1978. The characterization of the serotype 3 canine rotavirus isolate $(\mathrm{K} 9)$ that was used as a control has been described previously $(9,24)$. Fecal samples from foals in Kentucky were identified as rotavirus positive by latex agglutination (Virogen Rotatest; Wampole Laboratories, Cranbury, N.J.), and fecal samples from foals in New York State and Texas were identified as rotavirus positive by an enzyme-linked immunosorbent assay (23). 
The method for virus isolation has been described previously (22). Briefly, $25 \%$ fecal samples in phosphate-buffered saline were centrifuged at $8,000 \times g$, diluted to a final concentration of $2.5 \%$ in serum-free Eagle minimum essential medium containing $10 \mu \mathrm{g}$ of trypsin per $\mathrm{ml}$, and incubated at $37^{\circ} \mathrm{C}$ for $24 \mathrm{~h}$ in cover slip-containing tubes in a roller apparatus. The cover slips were removed at $24 \mathrm{~h}$, and rotavirus infection was demonstrated by immunofluorescence (24). The viruses were passaged at the onset of a cytopathic effect after 24 to $72 \mathrm{~h}$. All isolates were serotyped at low passage (usually 3 to 5 ) without cloning.

Extraction and electropherotyping of genomic RNA. RNA was extracted from tissue culture-adapted isolates by previously described methods (9). Briefly, viruses were purified by ultrapelleting through a $40 \%$ sucrose cushion at $100,000 \times$ $g$ and were then resuspended in sodium acetate with $1 \%$ sodium dodecyl sulfate. RNA was extracted first with phenol, then with 1:1 phenol-chloroform, and finally with chloroform and was precipitated with 4 volumes of ethanol at $-20^{\circ} \mathrm{C}$ overnight. RNA extraction from fecal specimens was done as described above, with the following additional steps performed as described by Theil et al. (19). Fecal samples were made to $25 \%$ with phosphate-buffered saline and centrifuged at $8,000 \times g$, and the supernatant was extracted twice with trichlorotrifluoroethane prior to ultrapelleting.

Precipitated RNA was pelleted at $-10^{\circ} \mathrm{C}$ and $2000 \times g$, vacuum dried, and resuspended in Laemmli sample buffer. The samples were electrophoresed in $7.5 \%$ sodium dodecyl sulfate-polyacrylamide gels at a constant current, and segments were visualized by staining with silver nitrate.

Serotyping (neutralization test). The serotyping method that we used has been described previously (24). The titer of an antiserum with a particular virus was determined as the reciprocal of the dilution that neutralized $50 \%$ or more of the immunofluorescent focus-forming units.

Monoclonal antibody 159, which is specific for VP7 of serotype 3 rotaviruses (18), was kindly supplied by $\mathrm{H}$. Greenberg, Gastroenterology, Veterans Administration Hospital, Palo Alto, Calif.

For the production of hyperimmune antisera, both the $\mathrm{H}-1$ and $\mathrm{H}-2$ strains were cultured and pelleted through $40 \%$ sucrose at $100,000 \times g$. For vaccine production, $1 \mathrm{ml}$ of concentrated virus with an infectivity titer of approximately $10^{9}$ was emulsified with $1 \mathrm{ml}$ of either Freund complete or Freund incomplete adjuvant. Guinea pigs were inoculated intramuscularly with $0.2 \mathrm{ml}$ of the Freund complete vaccine, followed 3 weeks later by inoculation with $0.2 \mathrm{ml}$ of virus emulsified in incomplete adjuvant, and blood samples were obtained after 3 weeks.

Serologic survey. For a serologic survey of the incidence of serotype 3 and 5 rotavirus infections in the Kentucky study, blood samples were obtained from the mares when the foals were sampled for diarrhea. These sera were tested for their titers to both H-1 and H-2 strains by the neutralization test. Analysis of variance was used to test for differences between the geometric mean serum antibody titers to $\mathrm{H}-1$ and $\mathrm{H}-2$.

\section{RESULTS}

Serotyping. The homologous neutralizing titers of both $\mathrm{H}-1$ and $\mathrm{H}-2$ antisera were 64,000 . Rotavirus isolates E7, E161, FI-13, FI-14, and KY-1 and eight tissue cultureadapted isolates from the Kentucky study were serotyped and compared with $\mathrm{H}-1$ and $\mathrm{H}-2$. The $\mathrm{H}-1$ and $\mathrm{H}-2$ antiserum titers to these viruses are given in Table 1 . The neutralizing
TABLE 1. Neutralization titers of serotype 3 and 5 typing hyperimmune antisera to tissue culture-adapted equine rotavirus isolates

\begin{tabular}{lrr}
\hline \multirow{2}{*}{$\begin{array}{c}\text { Virus } \\
\text { serotype) }\end{array}$} & \multicolumn{2}{c}{ Titer with typing antiserum: } \\
\cline { 2 - 3 } & \multicolumn{1}{c}{ H-2 } & H-1 \\
\hline H-2 (3) & 64,000 & $<1,000$ \\
H-1 (5) & 1,000 & 64,000 \\
K9 $(3)^{a}$ & 128,000 & 4,000 \\
E7 & 32,000 & $<1,000$ \\
E26 & 64,000 & $<1,000$ \\
E30 & 32,000 & $<1,000$ \\
E48 & 64,000 & $<1,000$ \\
E50 & 16,000 & $<1,000$ \\
E56 & 32,000 & $<1,000$ \\
E77 & 32,000 & $<1,000$ \\
E143 & 32,000 & $<1,000$ \\
E149 & 32,000 & $<1,000$ \\
E161 & 32,000 & $<1,000$ \\
FI-13 & 64,000 & $<1,000$ \\
FI-14 & 64,000 & $<1,000$ \\
KY-1 & 64,000 & $<1,000$ \\
\hline
\end{tabular}

${ }^{a}$ Serotype 3 canine rotavirus control.

titers of $\mathrm{H}-1$ antiserum to all of the viruses were less than 1,000 . Because there was at least a 20 -fold difference between the $\mathrm{H}-1$ and the $\mathrm{H}-2$ titers, the viruses were defined as serotype 3.

Isolate FI-13 has been reported to be serotypically different from $\mathrm{H}-2$ rotavirus (12), based on unpublished data (2) that antiserum to $\mathrm{H}-2$ neutralized FI-13 but that antiserum to FI-13 failed to neutralize H-2. For further characterization of FI-13 in this study, the neutralization titers of monoclonal antibody 159 were compared for FI-13, FI-14, and H-2. These titers were $320,2,560$, and 5,120, respectively.

Electropherotyping. Of 86 fecal samples analyzed, 32 were positive for rotavirus RNA, including those isolates subsequently adapted to tissue culture. None of the isolates demonstrated an RNA electrophoretic migration pattern characteristic of $\mathrm{H}-1$. All isolates showed minor variations in some of the segments but had overall electropherotype patterns that were similar to that of H-2. Tissue cultureadapted rotaviruses representative of the various patterns are shown in Fig. 1. The majority of the individual segment variations occurred in the migration patterns of segments 7 , 8 , and 9 and in the relative migration of segments 10 and 11 as a pair. The variations in the migrations of segments 7 to 9 were limited, in that three distinct patterns were consistently observed. Segments 7 and 8 ran close, segments 8 and 9 ran close, or segments 7,8 , and 9 were equidistant, with most isolates demonstrating a pattern in the 7-to-9 region similar to those of the FI-13 and FI-14 isolates. These patterns were distinct from that of $\mathrm{H}-1$, in which segments 8 and 9 comigrated and could not be distinguished from each other. Segments 10 and 11 exhibited variations in migration as pairs, either running longer or shorter as a whole than segments 10 and 11 of $\mathrm{H}-2$ did. The patterns of these two segments were distinct from that of $\mathrm{H}-1$, in that segments 10 and 11 of this strain ran closer together than segments 10 and 11 of H-2 or any of the isolates analyzed did.

Variations in gene migration between isolates were less obvious in segments 1 to 6 , which remained relatively constant between isolates run on the same gel. Some shifts were observed in segments 1 to 4 , which ran slightly shorter or longer as a group, but they displayed a pattern distinctive 


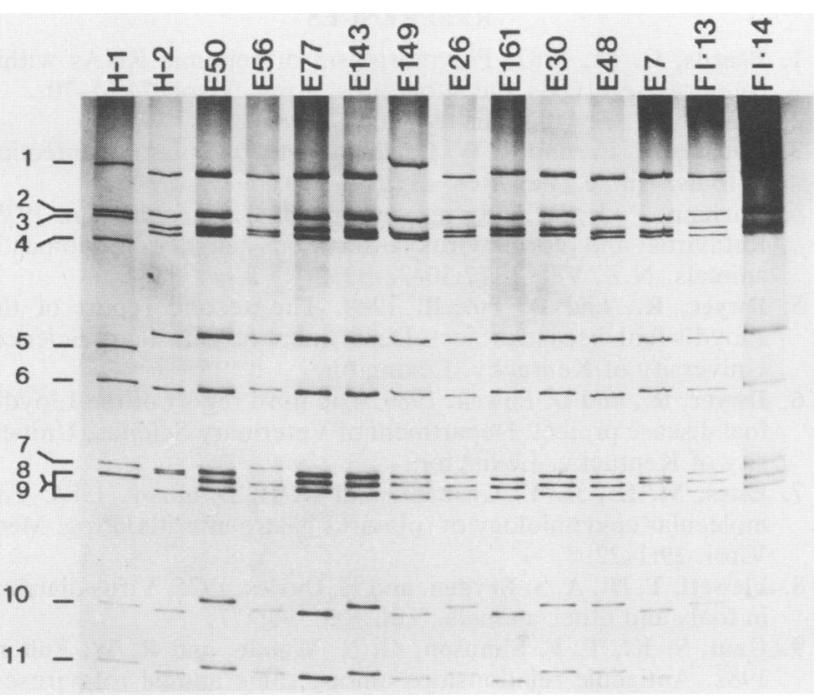

FIG. 1. Comparison of genomic RNA electrophoretic migration patterns of equine rotavirus tissue culture-adapted isolates by sodium dodecyl sulfate-polyacrylamide gel electrophoresis. Numbers on the left are gene segments.

from those of segments 1 to 4 of H-1. Segments 5 and 6 remained essentially invariant. Whether the near consistency within segments 1 to 6 was present between every isolate could not be determined, because all the samples could not be run on the same gel and were not coelectrophoresed. The electropherotype pattern of strain $\mathrm{KY}-1$ isolated in 1978 (data not shown) was similar to that of $\mathrm{H}-2$, with the same minor variations observed as were observed with the other isolates.

Tissue culture-adapted rotaviruses and the fecal specimens from which they were isolated showed very similar, if not identical, electropherotype patterns as pairs, examples of which are shown in Fig. 2. There was no evidence of mixed infections with rotaviruses with different electropherotypes in the fecal specimens, because none of the samples exhibited more than 11 segments.

Serologic survey. The results of the serologic survey of mares for antibodies to $\mathrm{H}-1$ and $\mathrm{H}-2$ rotaviruses are summarized in Table 2 . Only one sample had a titer to H-1 (titer, 100) greater than that to $\mathrm{H}-2$ (titer, 50). The ratios of $\mathrm{H}-2$ titers to $\mathrm{H}-1$ titers are presented in Table 3. A total of $77.17 \%$ of the serum samples demonstrated ratios greater than 2 , representing at least a fourfold difference in titers to the two viruses. There was a significant difference $(P<0.0001)$ between the geometric mean titers to $\mathrm{H}-1$ (1.95) and $\mathrm{H}-2$ (2.70).

\section{DISCUSSION}

The virus isolation, serology, and electropherotyping data presented here suggest that the predominant, or only, rotavirus strain present in the equine population in the United States is serotype 3 strain $\mathrm{H}-2$. All of the viruses isolated from fecal specimens and subsequently adapted to tissue culture were determined to be serotype 3 by reaction with hyperimmune antiserum specific for $\mathrm{H}-2$.

The RNA electrophoretic migration patterns of the tissue culture-adapted rotaviruses as well as rotavirus RNA extracted directly from fecal specimens all were similar to the

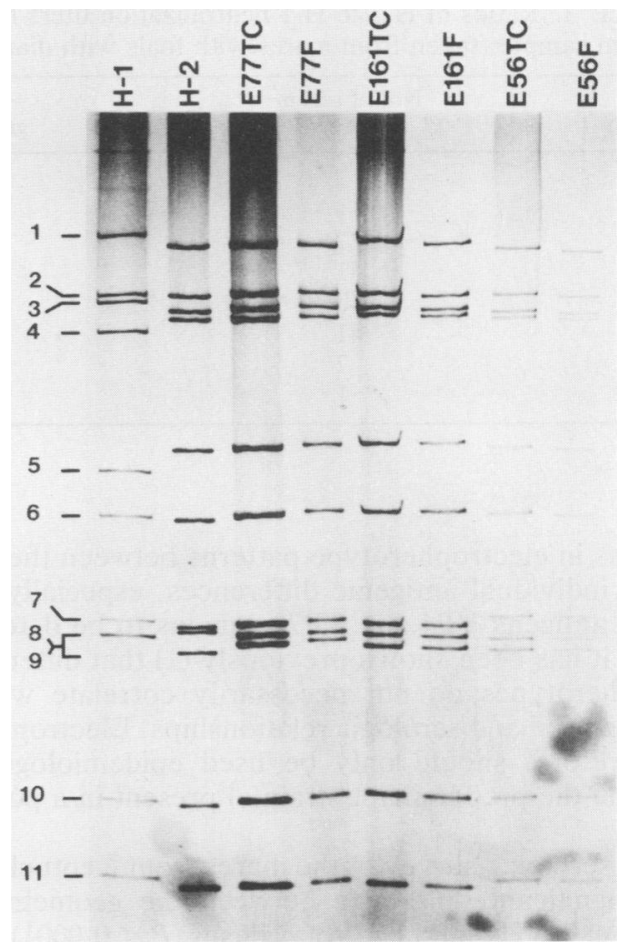

FIG. 2. Comparison of viral RNA electropherotypes of tissue culture-adapted rotaviruses and the respective fecal specimens from which they were isolated by sodium dodecyl sulfate-polyacrylamide gel electrophoresis. TC, Tissue culture isolate; F, fecal isolate. Numbers on the left are gene segments.

electropherotype pattern of $\mathrm{H}-2$. The tissue culture-adapted viruses and the RNA of the fecal specimens from which they were isolated showed electropherotype patterns that were very close, if not identical, as pairs, indicating that the predominant strain in the feces was represented in the properties of the tissue culture isolate. None of the patterns were similar to the distinct migration pattern of $\mathrm{H}-1$, suggesting the presence of one predominant strain that is electropherotypically close to $\mathrm{H}-2$.

The limited variation present in the migration patterns of gene segments 1 to 4,5 and 6,7 to 9, and 10 and 11 as groups suggests limited strain variation, at least electropherotypically, among the equine rotaviruses isolated in the United States in the 10-year period under study. Whether the

TABLE 2. Comparison of $\mathrm{H}-1$ and $\mathrm{H}-2$ neutralization titers for 184 serum samples taken from mares with foals with diarrhea

\begin{tabular}{rrrrrrr}
\hline \multirow{2}{*}{ H-2 titer } & \multicolumn{6}{c}{ No. of sera with the following titer of antibody to H-1: } \\
\cline { 2 - 7 } & 50 & 100 & 200 & 400 & 800 & Total \\
\hline 50 & 11 & 1 & 0 & 0 & 0 & 12 \\
100 & 12 & 1 & 0 & 0 & 0 & 13 \\
200 & 20 & 5 & 1 & 0 & 0 & 26 \\
400 & 19 & 16 & 7 & 1 & 0 & 43 \\
800 & 25 & 16 & 7 & 2 & 0 & 50 \\
1,600 & 4 & 11 & 4 & 7 & 1 & 27 \\
3,200 & 1 & 3 & 3 & 2 & 1 & 10 \\
6,400 & 0 & 0 & 0 & 2 & 1 & 3 \\
& & & & & & \\
Total & 92 & 53 & 22 & 14 & 3 & 184 \\
\hline
\end{tabular}


TABLE 3. Ratios of $\mathbf{H}-2$ to $\mathrm{H}-1$ neutralization titers for 184 serum samples taken from mares with foals with diarrhea

\begin{tabular}{rcc}
\hline Ratio & $\begin{array}{c}\text { No. of serum } \\
\text { specimens }\end{array}$ & $\begin{array}{c}\% \text { with a } \\
\text { greater ratio }\end{array}$ \\
\hline 0.5 & 1 & 99.46 \\
1.0 & 14 & 91.85 \\
2.0 & 27 & 77.17 \\
4.0 & 51 & 49.45 \\
8.0 & 42 & 26.62 \\
16.0 & 41 & 4.34 \\
32.0 & 7 & 0.54 \\
64.0 & 1 & 0.00 \\
\hline
\end{tabular}

variations in electropherotype patterns between the isolates indicate individual antigenic differences, especially in neutralizing antigens VP4 and VP7, remains to be determined, because it has been shown previously (1) that differences in electropherotypes do not necessarily correlate with antigenic variation and serologic relationships. Electropherotyping, therefore, should only be used epidemiologically to determine the predominant strain(s) present in a population (7).

In the serologic survey of the mares from Kentucky, there was a significant difference between the geometric mean serum titers to $\mathrm{H}-1$ and $\mathrm{H}-2$ rotaviruses $(P<0.0001)$, and for $77.17 \%$ of the samples, the difference in the ratio of $\mathrm{H}-2$ to $\mathrm{H}-1$ titers was greater than 2 , indicating at least a fourfold difference in titer. It is possible that the neutralizing antibodies to $\mathrm{H}-1$ rotavirus in mares originated as a cross-reactive response to $\mathrm{H}-2$. These serologic results support the data from virus isolation attempts that $\mathrm{H}-2$ is the more common infecting virus and, possibly, that infection with $\mathrm{H}-1$ virus does not occur in the United States. However, H-2 may be more readily adapted to tissue culture replication than $\mathrm{H}-1$ is, and further studies are required to provide an answer to this question.

From previous data (unpublished data), hyperimmune antisera to FI-13 did not neutralize H-2. This appears to represent a one-way cross-reaction, because the data presented here show that hyperimmune antiserum to $\mathrm{H}-2$ neutralizes FI-13. Further evidence was obtained in this study that FI-13 is an antigenic variant from $\mathrm{H}-2$, because VP7specific serotype 3 monoclonal antibody 159 had a 16-fold lower titer to FI-13. One-way relationships such as those observed between $\mathrm{H}-2$ and FI-13 may exist between the viruses isolated in the present study, but this was not determined, because none of the viruses were tested with antiserum made to each of the other isolates. A similar one-way relationship exists between two serotype 6 bovine rotaviruses (strains NCDV and B641). It has been suggested that these two viruses do not share the same or closely related gene $4(22,24)$. It is possible that FI-13 shares VP4, but not VP7, with $\mathrm{H}-2$. The equine rotaviruses isolated to date have not been compared for their VP4 properties.

\section{ACKNOWLEDGMENTS}

We thank Andra Voges, Paul Herrera, and Grace Mason for technical assistance and W. W. Romane and M. J. Sachs for the rotavirus-containing fecal samples from Texas and New York State, respectively.

This research was supported by the Texas Agricultural Experiment Station.

\section{REFERENCES}

1. Beards, G. M. 1982. Polymorphism of genomic RNAs within rotavirus serotypes and subgroups. Arch. Virol. 74:65-70.

2. Conner, M. E. Unpublished data.

3. Conner, M. E., and R. W. Darlington. 1980. Rotavirus infection in foals. Am. J. Vet. Res. 41:1699-1703.

4. Durham, P. J., B. J. Stevenson, and B. C. Farquharson. 1979. Rotavirus and coronavirus associated diarrhea in domestic animals. N.Z. Vet. J. 27:30-32.

5. Dwyer, R., and D. Powell. 1988. The second report of the Lloyd's foal disease project. Department of Veterinary Science, University of Kentucky, Lexington.

6. Dwyer, R., and D. Powell. 1989. The third report of the Lloyd's foal disease project. Department of Veterinary Science, University of Kentucky, Lexington.

7. Estes, M. K., D. Y. Graham, and D. H. Dimitrov. 1984. The molecular epidemiology of rotavirus gastroenteritis. Prog. Med. Virol. 29:1-22.

8. Flewett, T. H., A. S. Bryden, and H. Davies. 1975. Virus diarrhea in foals and other animals. Vet. Rec. 96:477.

9. Gaul, S. K., T. F. Simpson, G. N. Woode, and R. W. Fulton. 1982. Antigenic relationships among some animal rotaviruses: virus neutralization in vitro and cross-protection in piglets. $\mathbf{J}$. Clin. Microbiol. 16:495-503.

10. Gillespie, J., A. Kalica, M. Conner, E. Schiff, M. Barr, D. Holmes, and M. Frey. 1984. The isolation, propagation and characterization of tissue-cultured equine rotaviruses. Vet. Microbiol. 9:1-14.

11. Greenberg, H. B., J. Valdesuso, K. van Wyke, K. Midthun, M. Walsh, V. McAuliffe, R. G. Wyatt, A. R. Kalica, J. Flores, and Y. Hoshino. 1983. Production and preliminary characterization of monoclonal antibodies directed at two surface proteins of rhesus rotavirus. J. Virol. 47:267-275.

12. Higgins, W. P., J. H. Gillespie, E. I. Schiff, N. N. Pennow, and M. J. Tanneberger. 1988. Infectivity and immunity studies in foals with cell culture-propagated equine rotaviruses, p. 241247. In D. G. Powell (ed.), Equine infectious diseases V: proceedings of the fifth international conference. The University of Kentucky Press, Lexington.

13. Hoshino, Y., R. G. Wyatt, H. B. Greenberg, J. Flores, and A. Z. Kapikian. 1984. Serotypic similarity and diversity of rotaviruses of mammalian and avian origin as studied by plaque-reduction neutralization. J. Infect. Dis. 149:694-702.

14. Hoshino, Y., R. G. Wyatt, H. B. Greenberg, A. R. Kalica, and J. Flores. 1983. Isolation and characterization of an equine rotavirus. J. Clin. Microbiol. 18:585-591.

15. Hoshino, Y., R. G. Wyatt, H. B. Greenberg, A. R. Kalica, and J. Flores. 1983. Isolation, propagation, and characterization of a second equine rotavirus serotype. Infect. Immun. 41:10311037.

16. Kanitz, C. L. 1976. Identification of an equine rotavirus as a cause of neonatal foal diarrhea. Proceedings of the 22nd Annu. Convention Am. Assoc. Equine Pract., p. 155-165. American Association of Equine Practitioners, Golden, Colo.

17. Offit, P. A., H. F. Clark, G. Blavat, and H. B. Greenberg. 1986. Reassortant rotaviruses containing structural proteins $\mathrm{vp} 3$ and vp7 from different parents induce antibodies protective against each parental serotype. J. Virol. 60:491-496.

18. Shaw, R. D., P. T. Vo, P. A. Offit, B. S. Coulson, and H. B. Greenberg. 1986. Antigenic mapping of the surface proteins of rhesus rotavirus. Virology 155:434-451.

19. Theil, K. W., C. M. McCloskey, L. J. Saif, D. R. Redman, E. H. Bohl, D. D. Hancock, E. M. Kohler, and P. D. Moorhead. 1981. Rapid, simple method of preparing rotaviral double-stranded ribonucleic acid for analysis by polyacrylamide gel electrophoresis. J. Clin. Microbiol. 14:273-280.

20. Tzipori, S., and M. Walker. 1978. Isolation of rotavirus from foals with diarrhoea. Aust. J. Exp. Biol. Med. Sci. 56:453457.

21. Woode, G. N., J. C. Bridger, J. M. Jones, T. H. Flewett, A. S. Bryden, and G. B. B. White. 1976. Morphological and antigenic relationships between viruses (rotaviruses) from acute gastroenteritis of children, calves, piglets, mice, and foals. 
Infect. Immun. 14:804-810.

22. Woode, G. N., N. E. Kelso, T. F. Simpson, S. K. Gaul, L. E. Evans, and L. Babiuk. 1983. Antigenic relationships of some bovine rotaviruses: serum neutralization and cross-protection in gnotobiotic calves. J. Clin. Microbiol. 18:358-364.

23. Woode, G. N., S. L. Zheng, B. I. Rosen, N. Knight, N. E. Gourley, and R. F. Ramig. 1987. Protection between different serotypes of bovine rotavirus in gnotobiotic calves: specificity of serum antibody and coproantibody responses. J. Clin. Microbiol. 25:1052-1058.

24. Zheng, S., G. N. Woode, D. R. Melendy, and R. F. Ramig. 1989. Comparative studies of the antigenic polypeptide species VP4, VP6, and VP7 of three strains of bovine rotavirus. J. Clin. Microbiol. 27:1939-1945. 